\title{
The Effects of Irrigation Level and Genotype on Pod-Filling Related Traits in Peanut (Arachis hypogaea)
}

\author{
Kapil Gupta ${ }^{1}$, Oren Buchshtab ${ }^{2} \&$ Ran Hovav ${ }^{1}$ \\ ${ }^{1}$ Department of Field and Vegetable Crops, Plant Sciences Institute, ARO (Volcani Center), Bet Dagan, Israel \\ ${ }^{2}$ Yaham Ltd., Magen 1, Magen, Israel \\ Correspondence: Ran Hovav, Department of Field and Vegetable Crops, Plant Sciences Institute, ARO (Volcani \\ Center), Bet Dagan 50250, Israel. Tel: 972-3-968-3682. E-mail: ranh@agri.gov.il
}

Received: July 8, 2014 Accepted: November 16, 2014 Online Published: December 15, 2014

doi:10.5539/jas.v7n1p169

URL: http://dx.doi.org/10.5539/jas.v7n1p169

\begin{abstract}
In peanut (Arachis hypogaea), pod-filling is an important biological stage that is strongly influenced by the availability of water. It also has genetic component; since genotypes vary considerably in their pod-filling potential. We studied the effects of irrigation level, genotype and the Irrigation Level $\times$ Genotype interaction on pod-filling and other pod-related traits of peanut. Four peanut genotypes, including three Virginia-types and one Peruvian-type which differ considerably in their pod-filling potential, were examined under field conditions. Four irrigation treatments were applied $(60 \%, 80 \%, 100 \%$ and $120 \%)$ in a factorial experimental design. A significant irrigation-treatment effect was observed for the two main pod-filling related traits, meat content and dead-end ratio, in all of the genotypes studied. The irrigation level significantly affected gross pod weight, 100-pod weight and 100-seed weight, but did not have any significant effects on pod yield per plot or pod size distribution. Therefore, our study suggests that reduction in irrigation directly influence the developing pods, as a result of low water availability/potential in the pod's surrounding environment. The effect of irrigation was most significant at the lowest irrigation level $(60 \%)$; whereas a milder effect was observed in the $80 \%$ irrigation treatment, indicating that, in some cases, it is possible to reduce irrigation down to $80 \%$ without affecting the pod-filling components. Although the Irrigation $\times$ Genotype interaction was not statistically significant, some genotypes were found to be more strongly affected by the low-irrigation treatments. Also, irrigation level significantly affected the incidence of pod wart and the pod color variables, suggesting that higher irrigation should be applied in order to address these marketing-related traits. This trial serves as a fundamental study for understanding the pod-filling components that are influenced by the irrigation level in peanut.
\end{abstract}

Keywords: irrigation, peanut, pod-filling, pod yield

\section{Introduction}

Leguminous plants accumulate proteins, oils and carbohydrates in their seeds during a relatively prolonged phase termed pod-filling. During this period, rapid metabolic and morphological (size, weight and color) changes occur, involving cellular processes that include cell expansion and the beginning of desiccation (Rubel, Rinne, \& Canvin, 1972; Mienke, Chen, \& Beachy, 1981; Agrawal \& Thelen, 2006). At the beginning of pod development, the shell or pericarp accounts for the majority of the fruit volume (Clements, Dracup, \& Galwey, 2002). This maternal, vascularized tissue serves as an intermediate source of carbohydrates and amino acids, which are transferred from the primary leaves (source) to the seed embryo (sink). During the later stages of maturation, seeds accumulate nutrients and expand up to the point that, in some legumes the seeds fill the majority of the total pod volume.

Studies have shown that insufficient water availability during pod-filling is a major factor responsible for lower yield in legumes (Momen, Carlson, Shaw, \& Arjmand, 1979; Kadhem, Sprecht, \& Williams, 1985; Sorooshzadeh $\&$ Barthakur, 1995). For example, in soybean, it was shown that while the water status of developing seeds is not altered by short-term water deficits, in cases of long-term water deficits, water potential and the activities of both the pericarp and the seed are decreased, inhibiting seed development (Westgate, Schussler, Reicosky, \& Brenner, 1989). Therefore, it is suggested that the maintenance of a favorable water level is important for seed growth in soybean under dry conditions (Westgate \& Grant, 1989). Pod-filling in legumes has a strong genetic component as well. Variation between different soybean cultivars with regard to pod-filling potential under water-deficit 
conditions has been observed (Momen et al., 1979). In Lupinus, the proportion of seed to pericarp and seed coat, which is another maternal intermediate source for nutrients, was found to be affected by both genetic and environmental conditions (Clements et al., 2002; Mera, Jerez, Miranda, \& Rouan, 2004). In pea (Pisum sativum), a strong genetic effect and high levels of heritability were observed for rate of pod-filling and final pod weight in crops grown at different field locations and in different seasons (Mahon \& Hobbs, 1983).

A unique example of the effect of water stress on pod-filling in legumes is presented by the peanut (Arachis hypogaea), the second most important cultivated grain legume crop in the world. Insufficient pod-filling is an important factor influencing peanut production both quantitatively and qualitatively. In the US peanut industry, for example, pod-filling (measured as "meat content") is one of the components sampled and graded by the Federal-State Inspection Services, to determine the overall quality and value of peanuts, alongside other characteristics like pod size, kernel size, moisture content, and the presence of damaged kernels and foreign material. In the within-shell industry, inadequate pod-filling is of particular concern as incomplete pod-filling of within-shell peanut cause severe burns during roasting, leading to sharp decreases in product price (Walerstein, 2003). Another pod filling-related defect is the dead-end phenomena, in which only some of the seeds in a pod are fully developed, while the other seeds (usually the most exterior) have not grown, leaving an undeveloped embryo. This trait is common in some cultivars with elongated pods and is also responsible for burns during the in-shell roasting process.

Long periods of water stress influence the growth rate of the peanut plant and can cause significant reductions in yield (Wright, Hubick, \& Farquhar, 1991; Reddy, Reddy, \& Anbumozhi, 2003; Soler, Suleiman, Anothai, Flitcroft, \& Hoogenboom, 2013). Since peanut is a unique legume, in which pods develop underground, the development of peanut pods is also directly influenced by the water conditions of the surrounding soil medium (Underwood, Taylor, \& Hoveland, 1971). At the beginning of pod development, the pegs (gynophores) contain root hair-like structures and function like roots as they absorb water and nutrients (Moctezuma, 2003). Later, the developing pods no longer function as a root, but water and nutrients such as calcium are still absorbed by the outer shell layer and this absorption process is essential for proper seed development (Smal, Kvien, Summer, \& Csinos, 1989; Zharare, Blamey, \& Asher, 2009). Therefore, the pod-filling process might be vulnerable to minimal reductions in soil moisture even when no impact is observed on the mother plant. It has been shown that when the water content of the soil is low, fewer pegs develop into pods (Ono, Nakayama, \& Kubota, 1974; Harris, Matthews, Nageswara Rao, \& Williams, 1988). In response to reductions in moisture availability, peanut pod size decreases and its osmotic concentration increases (Boote, Varnell, \& Duncan, 1976). Some other studies have also shown that the water activity of the pod wall (pericarp) controls the water balance of the kernels at later developmental stages, which are critical to pod-filling under short-term water-deficit conditions (Heuer et al., 1994; Dorner, 2008). Therefore, pod-filling in peanut is particularly sensitive to irrigation levels during the late-developmental and maturation stages.

Pod-filling in peanut also has a significant genetic component and cultivars vary considerably in their pod-filling and seed-filling potentials (Rao Nageswara, Williams, \& Singh, 1989; Sorooshzadeh \& Barthakur, 1995). In Israel, some cultivars (e.g., A80) suffer from incomplete pod-filling when grown under insufficient irrigation in sandy soils (Walerstein, 2003), yet others (e.g., 'Hanoch') are more tolerant of water deficits. Another example of a line that is sensitive to insufficient water availability is the Peruvian exotic line PI338338. A recent study showed that PI338338 is tolerant of pod wart, a disease caused by soil-borne bacteria from the Streptomyces genus that endangers the export-oriented in-shell industry (Shem-Tov, Chedvat, Brand, \& Hovav, 2011). However, preliminary observations have shown that this line suffers from incomplete pod-filling when grown under suboptimal water conditions (Hovav et al., 2012).

Since a considerable portion of worldwide within-shell peanut production is based in the light soils of the arid and semiarid tropics during the spring-summer season under partial or full irrigation, it is important to understand the effect of the level of irrigation on the pod-filling processes. Currently, most of the information regarding genetic and irrigation effects on peanut pod-filling is based on observations from commercial plots, while reports about planned field trials are relatively rare. Therefore, this study was designed to identify the effects of different levels of irrigation, genotypes and their interactions on pod-filling and other pod-related characteristics in an organized field trial.

\section{Materials and Methods}

\subsection{Plant Material and Irrigation Treatments}

Four genotypes, including two with good pod-filling potential ('Hanoch', A80) and two with incomplete pod-filling (53, B18) were used for the study. 'Hanoch' is the leading cultivar in the region, has a spreading 
growth habit, is late maturing and has high dead-end ratios. A80 is a bunch-type, early-maturing cultivar. B18 is a new breeding line with a bunch growth habit that is early-maturing and has extra-large pods. All three of these genotypes are Virginia-type peanuts (A. hypogaea spp. hypogaea). Line 53 is the local name for PI338338, a Peruvian peanut type (A. hypogaea spp. fastigiata var. peruviana) with high tolerance of pod wart. Plants were grown in a factorial experimental design with four blocks where genotype and irrigation levels were fixed factors. Four irrigation treatments were applied. These volumes were calculated based on 100\%, 120\%, 80\% and 60\% retention of applied water. There were four replications of each irrigation treatment (i.e., four blocks). The experiment was performed in a wheat-fallow field at the Israel Ministry of Agriculture Southern R \& D Center, Negev, Israel. Each plot consisted of 8 ridges, each $193 \mathrm{~cm}$ in width and $200 \mathrm{~m}$ in length. Forty plants were planted by hand in each 8 -meter plot, with 2.5 plants $/ \mathrm{m}$. Plant water intake was determined using a lysimeter system that included two devices that measure the plants' actual evapotranspiration by recording the amount of precipitation that an area $(80 \mathrm{~cm} \times 96 \mathrm{~cm} \times 80 \mathrm{~cm})$ receives and the amount of moisture lost from the soil. The irrigation system included sprinklers every 2 ridges and 6-m spacing along the lines, with an autonomic operating system for each subplot (64 plots in total). No rainfall was occurred in this region during the period of the experiment.

\subsection{Determination of Pod Characteristics}

All 64 plots ( 4 genotypes $\times 4$ irrigation treatments $\times 4$ blocks) were uprooted and harvested during the first week of October 2013. Total pod yield per plot (Y) was determined by hand-threshing and weighing the yield (in $\mathrm{kg}$ ). Two hundred and fifty pods were then collected randomly from each plot to determine the average gross pod weight (GPW; g), incidence of undeveloped pods (UP; \%), incidence of single pods (S; \%) and the incidence of pod wart (W; \%) in that plot. One hundred fully mature ("real") pods were then randomly collected from the 250 "gross" pods (including pods with pod warts) and were used to determine 100-pod weight (PW; g), 100-seed weight (SW; g), and meat content (MC; \% seeds/pods). The dead-end ratio (DE; \%) was determined by counting the pods that had an undeveloped seed at the distal part of the pod. For oil extraction, $5 \mathrm{~g}$ of mature seeds were ground in an Abencor laboratory mill (Mc2 Ingenieria Y Sistemas, Seville, Spain) and dried for $24 \mathrm{~h}$. The total oil content was than determined by a Soxhlet extraction using n-hexane.

To evaluate pod size distribution, $1.2 \mathrm{~kg}$ of the total gross pods were sampled from each plot of the three Virginia-type genotypes ('Hanoch', A80 and B18) and subjected to size distribution analysis with the sorting machine at the Field Produce, Ltd. sampling center. Pods were sorted into four groups: super giant (6-8 pods/oz.), giant (7-9 pods/oz.), fancy (9-14 pods/oz.) and -14 (>14 pods/oz.).

Measurements of the color variables of pods of Virginia genotypes from each plot were collected. Mature, pathogen-free pods were randomly selected and their color variables were recorded. Pods were baked in an oven at $70{ }^{\circ} \mathrm{C}$ for $24 \mathrm{~h}$ to ensure that they were completely dry before the readings were taken. Colors were determined using a portable spectrophotometer spectro-guide CC-6800 (BYK-Gardner, Columbia, MD) and evaluated in terms of the $\mathrm{L}^{*} \mathrm{a}^{*} \mathrm{~b}^{*}$ model that presents color in a three-dimensional space. The three basic coordinates represent the lightness of the color $\left(\mathrm{L}^{*}, \mathrm{~L}^{*}=0\right.$ yields black and $\mathrm{L}^{*}=100$ indicates white), its position between red/magenta and green $\left(\mathrm{a}^{*}\right.$, negative values indicate green while positive values indicate magenta) and its position between yellow and blue ( $b^{*}$, negative values indicate blue and positive values indicate yellow). The color value for each peanut shell was expressed in terms of an average of three readings at different locations on the shell surface.

\subsection{Statistical Analysis}

An ANOVA test was performed using the Fit Model function and the REML (Restricted Maximum Likelihood) method of the JMP software package (JMP, Version 10; SAS Institute Inc., Cary, NC) to evaluate the effects of irrigation treatment, genotype and the Irrigation $\times$ Genotype interaction on pod-related traits. The linear model that was used is shown below:

$$
Y_{i j k}=\mu+\alpha_{i}+\gamma_{j}+\alpha \gamma_{i j}+\beta_{k}+e_{i j k}
$$

In this model, $\mu$ is the grand mean, $\alpha_{i}$ is the genotype main effect ( $i=$ 'Hanoch', A80, B18, 53), $\gamma_{j}$ is the irrigation main effect $(j=60 \%, 80 \%, 100 \%, 120 \%), \alpha \gamma_{i j}$ is the Genotype $\times$ Irrigation interaction effect, $\beta_{k}$ is the block effect $(k=1,2,3,4)$ and $e_{i j k}$ is the effect of random error.

The difference between the effects of the genotypes and the irrigation treatments on the pod-filling traits (meat content, dead end) and other pod-related traits (pod yield, 100-seed weight, etc.) were evaluated by $t$-tests of their least square means (LSM) using the Fit Model function of the JMP software. 


\section{Results}

\subsection{The Effects of Genotype and Irrigation Level on Traits Related to Pod-Filling}

An ANOVA test was performed to evaluate the effects of irrigation treatment, genotype and the Irrigation $\times$ Genotype interaction on two pod filling-related traits: meat content (MC) and dead-end ratio (DE). The results of this analysis are shown in Table 1.

Table 1. ANOVA tests for the effects of four peanut genotypes, four irrigation levels and their interaction on two traits related to pod-filling. Significant factors $(\operatorname{Prob}(F)<0.05)$ are indicated by bold type

\begin{tabular}{llllll}
\hline Trait & Source & SS & DF & F ratio & Pro(F) \\
\hline MC (\%) & Block\&Random & 28 & 3 & 4.05 & $\mathbf{0 . 0 1 2 4}$ \\
& Irrigation & 160 & 3 & 23.25 & $<\mathbf{0 . 0 0 0 1}$ \\
& Genotype & 311 & 3 & 45.07 & $<\mathbf{0 . 0 0 0 1}$ \\
& Irrigation*Genotype & 21 & 9 & 1.03 & 0.4310 \\
\hline DE (\%) & Block\&Random & 109 & 3 & 3.04 & $\mathbf{0 . 0 3 8 7 0}$ \\
& Irrigation & 120 & 3 & 3.32 & $\mathbf{0 . 0 2 8 2 3}$ \\
& Genotype & 954 & 3 & 26.41 & $<\mathbf{0 . 0 0 0 1}$ \\
& Irrigation*Genotype & 164 & 9 & 1.51 & 0.1730
\end{tabular}

$\mathrm{MC}=$ meat content; $\mathrm{DE}=$ dead end.

We found that irrigation and genotype factors significantly affected MC and DE. The block factor also significantly affected both of these traits, indicating the significance of the experimental set-up for the analysis of the experimental factors under field conditions. The Irrigation $\times$ Genotype had no significant effect on $\mathrm{MC}$ or DE. Therefore, the differences between the genotypes and irrigation levels regarding $\mathrm{MC}$ and DE were estimated separately.

As expected, the Israeli Virginia-type cultivars 'Hanoch' and A80 had the highest MC levels, irrespective to the level of irrigation (Table 2). In particular, A80 had both the highest average MC level (74.6\%) and the lowest DE ratio (5.36\%). Genotypes B18 and 53 had the lowest $\mathrm{MC}$ values $(62.4 \%$ and $62.2 \%$, respectively), as expected from our previous observations. 'Hanoch', a spreading Virginia-type cultivar with long pods with large constriction, had the highest DE ratio (15.9\%) at all irrigation levels.

Table 2. Range $t$-test for differences between peanut genotypes and irrigation levels in terms of their effects on two traits related to pod-filling. Treatments that are not labeled with same letter are significantly different $(p<$ 0.05 ) from one another

\begin{tabular}{|c|c|c|c|c|c|}
\hline \multicolumn{4}{|l|}{ MC (\%) } & \multicolumn{2}{|l|}{ DE (\%) } \\
\hline Genotype & Mean \pm SE & Group & Genotype & Mean \pm SE & Group \\
\hline A80 & $74.61 \pm 0.39$ & A & Hanoch & $15.86 \pm 0.86$ & A \\
\hline Hanoch & $72.64 \pm 0.38$ & B & B18 & $13.22 \pm 0.86$ & B \\
\hline B18 & $69.44 \pm 0.38$ & $\mathrm{C}$ & 53 & $9.55 \pm 0.86$ & $\mathrm{C}$ \\
\hline 53 & $69.24 \pm 0.38$ & $\mathrm{C}$ & A 80 & $5.36 \pm 0.90$ & $\mathrm{D}$ \\
\hline Irrigation & Mean \pm SE & Group & Irrigation & Mean $\pm \mathrm{SE}$ & Group \\
\hline 120 & $72.68 \pm 0.37$ & A & 60 & $13.16 \pm 0.86$ & A \\
\hline 100 & $72.57 \pm 0.39$ & A & 80 & $11.12 \pm 0.90$ & $\mathrm{AB}$ \\
\hline 80 & $71.90 \pm 0.37$ & A & 100 & $10.13 \pm 0.86$ & B \\
\hline 60 & $69.77 \pm 0.37$ & B & 120 & $9.56 \pm 0.86$ & B \\
\hline
\end{tabular}

$\mathrm{MC}=$ meat content $\mathrm{DE}=$ dead end. 
No significant difference was found between the three highest irrigation levels $(120 \%, 100 \%$ and $80 \%)$ in terms of their effects on MC and DE. On the other hand, a decrease of at least $2 \%$ in $\mathrm{MC}$ was associated with the $60 \%$ irrigation treatment, as compared to the other irrigation treatments. The $60 \%$ irrigation treatment was also associated with the highest DE ratio (\%13.16), which was significantly different from the DE ratios observed for the $100 \%$ and $120 \%$ irrigation treatments, but not significantly different from the DE ratio observed for the $80 \%$ irrigation treatment. This means that irrigation level starts to impact $\mathrm{DE}$ at the $80 \%$ level and that this effect becomes significant at the $60 \%$ level. Collectively, these results indicate that low irrigation levels influence both meat content and dead-end ratios.

Although no significant Irrigation $\times$ Genotype interaction effect was observed for MC, some differences between the sensitivity of the different genotypes to lower irrigation levels were observed. For example, lines 53 and B18 were found to be more sensitive to the lower irrigation levels than the cultivars 'Hanoch' and A80, as measured in terms of MC. This effect is depicted in Figure 1, which shows that the MC of line 53 remained lower than that of 'Hanoch' at all four irrigation levels. However, in 'Hanoch', a significant reduction in MC was observed only at the $60 \%$ irrigation level. In Line 53, the effect was observed in the transition from $120 \%$ to $100 \%$ irrigation and was very significant in the transition from $80 \%$ to $60 \%$ irrigation. This result indicates that the pod-filling of both lines is affected by irrigation, but Line 53 seems to be more vulnerable than other lines to water stress, as expressed in its pod-filling potential at lower irrigation levels.

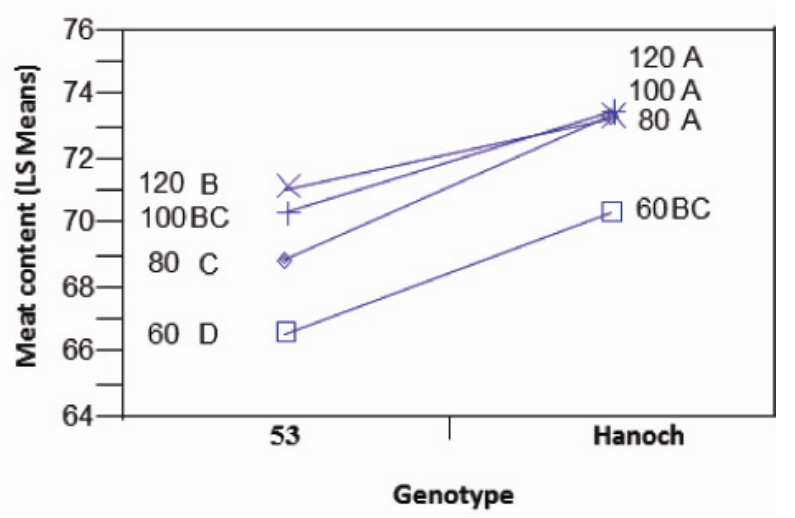

Figure 1. The effect of irrigation level on meat content of two peanut genotypes; 53 and Hanoch. Irrigation treatments that are not labeled with the same letter are significantly different from one another

\subsection{The Effects of Irrigation Level and Genotype on Other Characteristics Related to Pod Yield}

The significance of the irrigation level, genotype and interaction effects on other pod yield-related traits such as pod yield per plot (PY), pod gross weight (GPW), incidence of single pods (S), incidence of undeveloped pods (UP), 100-pod weight (PW), 100-seed weight (SW), oil content (OC) and pod wart infection (W) were evaluated as well (Table 3 ). Interestingly, while the irrigation treatment significantly affected both meat content and the dead-end ratio (Table 1), no such effect was observed for PY. A similar non-significant irrigation effect was observed for both S and OC. On the other hand, GPW, UP, PW, SW and W were all significantly affected by the irrigation level. Genotype significantly affected all of the examined agricultural traits, except for S (Table 3). The interaction of genotype and irrigation did not have a significant effect on any of the examined traits. Therefore, the differences between genotypes and the differences between the irrigation levels with relation to these traits were estimated separately. 
Table 3. ANOVA tests for the effects of four peanut genotypes, four irrigation levels and their interaction on characteristics related to pod yield. Significant factors (Prob $(F)<0.05$ ) are indicated by bold type

\begin{tabular}{|c|c|c|c|c|c|}
\hline Trait & Source & SS & $\mathrm{DF}$ & F ratio & Pro(F) \\
\hline \multirow[t]{4}{*}{$\mathrm{Y}$} & Block\&Random & 22 & 3 & 4.64 & 0.0065 \\
\hline & Irrigation & 6 & 3 & 1.33 & 0.2742 \\
\hline & Genotype & 68 & 3 & 14.10 & $<0.0001$ \\
\hline & Irrigation*Genotype & 4 & 9 & 0.32 & 0.9627 \\
\hline \multirow[t]{4}{*}{ GPW } & Block\&Random & 15436 & 3 & 1.86 & 0.1496 \\
\hline & Irrigation & 23499 & 3 & 2.83 & 0.0487 \\
\hline & Genotype & 122944 & 3 & 148.28 & $<0.0001$ \\
\hline & Irrigation*Genotype & 47544 & 9 & 1.91 & 0.0745 \\
\hline \multirow[t]{4}{*}{ UP } & Block\&Random & 176 & 3 & 2.70 & 0.0566 \\
\hline & Irrigation & 470 & 3 & 7.20 & 0.0004 \\
\hline & Genotype & 184 & 3 & 2.82 & 0.0493 \\
\hline & Irrigation*Genotype & 279 & 9 & 1.42 & 0.2060 \\
\hline \multirow[t]{4}{*}{$\mathrm{S}$} & Block\&Random & 18 & 3 & 0.59 & 0.6237 \\
\hline & Irrigation & 13 & 3 & 0.42 & 0.7334 \\
\hline & Genotype & 43 & 3 & 1.37 & 0.2635 \\
\hline & Irrigation*Genotype & 84 & 9 & 0.88 & 0.5435 \\
\hline \multirow[t]{4}{*}{ PW } & Block\&Random & 258 & 3 & 0.47 & 0.3849 \\
\hline & Irrigation & 1766 & 3 & 3.26 & 0.032 \\
\hline & Genotype & 270507 & 3 & 500.27 & $<0.0001$ \\
\hline & Irrigation*Genotype & 3335 & 9 & 2.05 & 0.07 \\
\hline \multirow[t]{4}{*}{ SW } & Block\&Random & 159 & 3 & 2.42 & 0.0799 \\
\hline & Irrigation & 209 & 3 & 3.18 & 0.0341 \\
\hline & Genotype & 77627 & 3 & 1179.04 & $<0.0001$ \\
\hline & Irrigation*Genotype & 161 & 9 & 0.81 & 0.6053 \\
\hline \multirow[t]{4}{*}{ W } & Block\&Random & 2187 & 3 & 7.28 & $<0.0001$ \\
\hline & Irrigation & 2462 & 3 & 8.19 & 0.0002 \\
\hline & Genotype & 5213 & 3 & 17.35 & $<0.0001$ \\
\hline & Irrigation*Genotype & 1032 & 9 & 1.14 & 0.3565 \\
\hline \multirow[t]{4}{*}{$\mathrm{OC}$} & Block\&Random & 243.826 & 3 & 1.7336 & 0.174 \\
\hline & Irrigation & 130.778 & 3 & 0.9298 & 0.4343 \\
\hline & Genotype & 551.057 & 3 & 3.9181 & 0.0145 \\
\hline & Irrigation*Genotype & 261813 & 9 & 0.6205 & 0.7731 \\
\hline
\end{tabular}

$\mathrm{Y}=$ pod yield per plot; GPW = gross pod weight; UP = undeveloped pods; $\mathrm{S}=$ singles; $\mathrm{PW}=100$-pod weight; $\mathrm{SW}=100$-seed weight; $\mathrm{W}=$ incidence of pod wart infection; $\mathrm{OC}=$ oil content.

The differences between the effects of the irrigation treatments on these pod yield-related traits were evaluated by $t$-tests of their least square means (Table 4). For all traits, non-significant differences were observed between the $100 \%$ and $120 \%$ irrigation levels. For GPW, PW and SW, the differences between the $100 \%$ irrigation level and the $120 \%$ irrigation treatments were noticeable, but not significant. Yet, in the transition to the lower irrigation levels, particularly to the $60 \%$ irrigation treatment, changes were observed in most of the traits. For example, UP was significantly increased from $6 \%$ in the normal $(100 \%)$ and high $(120 \%)$ irrigation treatments to 
$11 \%$ at the lower irrigation levels $(60 \%$ and $80 \%)$. In the same manner, GPW decreased from $741 \mathrm{~g}$ in the $80 \%$ irrigation treatment to $691 \mathrm{~g}$ in the $60 \%$ irrigation treatment. Interestingly, irrigation level influenced the incidence of pod wart infection; at the lower irrigation levels $(80 \%$ and $60 \%)$, a $40 \%$ increase in pod wart infection was observed.

Table 4. Range test for differences between irrigation levels in terms of pod yield-related traits. Treatments that are not labeled with the same letter are significantly different from one another. Only traits for which significant differences were observed are shown

\begin{tabular}{|c|c|c|c|c|c|}
\hline \multicolumn{3}{|l|}{ GPW(g) } & \multicolumn{3}{|l|}{ UP \% } \\
\hline Irrigation & Mean \pm SE & Group & Irrigation & Mean $\pm \mathrm{SE}$ & Group \\
\hline 100 & $741.13 \pm 13.14$ & A & 60 & $11.98 \pm 1.17$ & A \\
\hline 120 & $734.63 \pm 13.14$ & A & 80 & $10.27 \pm 1.21$ & A \\
\hline 80 & $724.06 \pm 13.14$ & $\mathrm{AB}$ & 100 & $6.13 \pm 1.17$ & B \\
\hline 60 & $691.31 \pm 13.14$ & B & 120 & $5.53 \pm 1.17$ & B \\
\hline \multicolumn{3}{|l|}{ PW( g) } & \multicolumn{3}{|l|}{$\mathrm{SW}(\mathrm{g})$} \\
\hline Irrigation & Mean \pm SE & Group & Irrigation & Mean \pm SE & Group \\
\hline 80 & $344.80 \pm 3.93$ & A & 80 & $124.18 \pm 1.15$ & A \\
\hline 120 & $337.43 \pm 3.63$ & $\mathrm{AB}$ & 100 & $124.06 \pm 1.15$ & A \\
\hline 100 & $335.95 \pm 3.63$ & $\mathrm{AB}$ & 120 & $121.06 \pm 1.15$ & $\mathrm{AB}$ \\
\hline 60 & $328.53 \pm 3.50$ & B & 60 & $119.56 \pm 1.15$ & B \\
\hline
\end{tabular}

\begin{tabular}{lll}
\hline $\mathrm{W}$ & & \\
\hline Irrigation & Mean $\pm \mathrm{SE}$ & Group \\
\hline 60 & $35.52 \pm 2.47$ & $\mathrm{~A}$ \\
80 & $33.30 \pm 2.47$ & $\mathrm{~A}$ \\
100 & $24.77 \pm 2.47$ & $\mathrm{~B}$ \\
120 & $20.22 \pm 2.47$ & $\mathrm{~B}$
\end{tabular}

GPW $=\overline{\text { gross pod weight, } \mathrm{UP}=\text { undeveloped pods; } \mathrm{PW}}=100$-pod weight; $\mathrm{SW}=100$-seed weight; $\mathrm{W}=$ pod wart infection.

Table 5 presents the differences between the genotypes in terms of the pod yield-related traits. Genotype A80 had the highest PY values (7.16 kg per plot), as compared to the other genotypes, with no effect of irrigation level. As expected, the B18 genotype that was bred to have extra-large pods had the highest GPW, PW and SW. This is despite the fact that B18 performed poorly in terms of the pod filling-related traits, with scores of $69.4 \%$ and $13.2 \%$ for MC and DE, respectively (Table 2). As expected, Line 53, which is considered a good breeding source for pod wart tolerance, had the lowest incidence of pod wart $(11 \%$ vs. an average of $33 \%$ for the other genotypes). It also had higher oil content than the other lines, but was inferior to the other genotypes in terms of the other agronomic traits. 
Table 5. Range test for differences between genotypes in terms of traits related to pod yield. Treatments that are not labeled with the same letter are significantly different from one another. Only traits for which significant differences were observed are shown

\begin{tabular}{|c|c|c|c|c|c|}
\hline \multicolumn{3}{|l|}{$\mathrm{Y}(\mathrm{Kg})$} & \multicolumn{3}{|l|}{ GPW(g) } \\
\hline Genotype & Mean $\pm \mathrm{SE}$ & Group & Genotype & Mean $\pm \mathrm{SE}$ & Group \\
\hline A80 & $7.16 \pm 0.31$ & $\mathrm{~A}$ & B18 & $835.63 \pm 13.14$ & A \\
\hline Hanoch & $6.17 \pm 0.31$ & B & A80 & $806.13 \pm 13.14$ & A \\
\hline B18 & $5.67 \pm 0.31$ & $\mathrm{~B}$ & Hanoch & $762.38 \pm 13.14$ & $\mathrm{~B}$ \\
\hline 53 & $4.29 \pm 0.31$ & $\mathrm{C}$ & 53 & $487.00 \pm 13.14$ & $\mathrm{C}$ \\
\hline \multicolumn{3}{|l|}{ UP \% } & \multicolumn{3}{|l|}{ PW (g) } \\
\hline Genotype & Mean $\pm \mathrm{SE}$ & Group & Genotype & Mean $\pm \mathrm{SE}$ & Group \\
\hline Hanoch & $10.02 \pm 1.21$ & $\mathrm{~A}$ & $\mathrm{~B} 18$ & $394.87 \pm 5.79$ & $\mathrm{~A}$ \\
\hline B18 & $9.93 \pm 1.16$ & A & Hanoch & $367.84 \pm 6.28$ & $\mathrm{~B}$ \\
\hline A 80 & $8.15 \pm 1.16$ & $\mathrm{AB}$ & A80 & $365.09 \pm 6.28$ & $\mathrm{~B}$ \\
\hline 53 & $5.80 \pm 1.16$ & $\mathrm{~B}$ & 53 & $216.50 \pm 6.28$ & $\mathrm{C}$ \\
\hline \multicolumn{3}{|l|}{ SW (g) } & \multicolumn{3}{|l|}{$\mathrm{W}$} \\
\hline Genotype & Mean $\pm \mathrm{SE}$ & Group & Genotype & Mean $\pm \mathrm{SE}$ & Group \\
\hline B18 & $149.1 \pm 0.90$ & A & A80 & $36.37 \pm 2.47$ & A \\
\hline A80 & $143.6 \pm 0.90$ & B & Hanoch & $34.67 \pm 2.47$ & A \\
\hline Hanoch & $140.6 \pm 0.90$ & $\mathrm{C}$ & B18 & $31.40 \pm 2.47$ & A \\
\hline 53 & $56.1 \pm 0.90$ & $\mathrm{D}$ & 53 & $11.37 \pm 2.47$ & B \\
\hline \multicolumn{6}{|l|}{$\mathrm{OC}(\mathrm{g})$} \\
\hline Genotype & Mean \pm SE & Group & & & \\
\hline 53 & $47.04 \pm 1.71$ & A & & & \\
\hline Hanoch & $44.11 \pm 1.78$ & $\mathrm{AB}$ & & & \\
\hline A 80 & $40.48 \pm 1.71$ & B & & & \\
\hline B18 & $39.72 \pm 1.71$ & B & & & \\
\hline
\end{tabular}

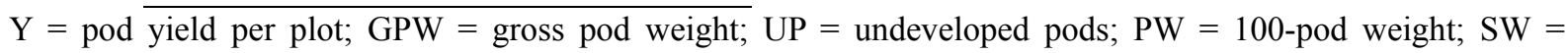
100-seed weight; $\mathrm{W}=$ pod wart infection; $\mathrm{S}=$ singles; $\mathrm{OC}=$ oil content.

\subsection{The Effects of Irrigation Level on Pod Size Distribution and Pod Color Variables in Virginia-Type Genotypes}

Pod size distribution and pod color are two important traits for the within-shell peanut industry. The differences between the three Virginia-type genotypes and the four irrigation levels were evaluated in terms of pod size distribution and pod color variables. Pod size distribution differed significantly among the three Virginia-type genotypes. 'Hanoch' had the highest proportion of giant pods; whereas A80 and B18 had the highest proportions of super-giant pods (Figure 2). 'Hanoch' had the highest proportions of extra-fancy and -14 pods as well. The test of the effect of the irrigation treatments on pod size distribution revealed an unexpected pattern. The $80 \%$ irrigation treatment had higher proportion of super-giant pods than observed for the $100 \%$ and $120 \%$ irrigation treatments, and lower proportion of giant pods. This pattern held true across all three genotypes (Figure 2). 
A.

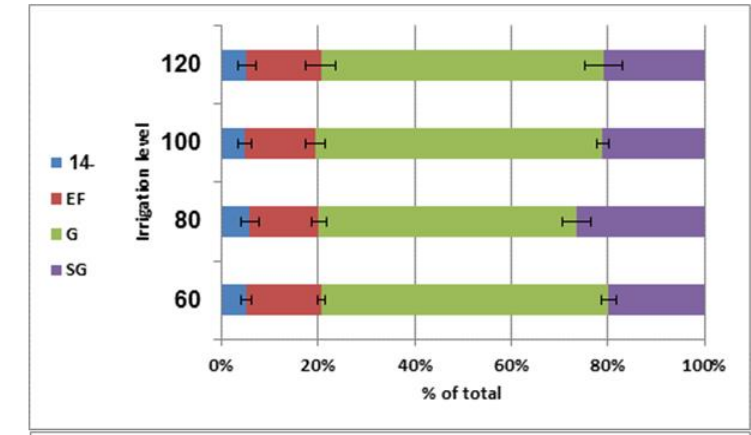

B.

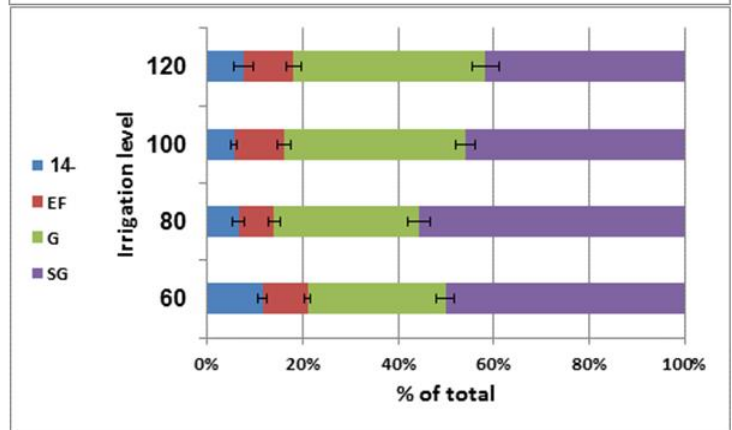

C.

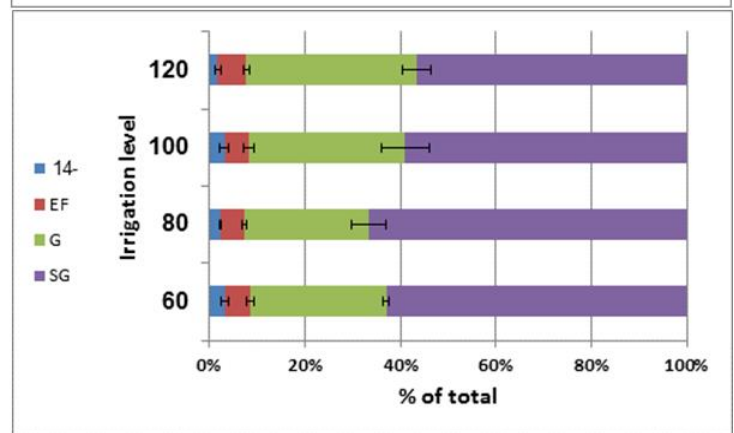

Figure 2. Pod size distribution of three Virginia genotypes subjected to four irrigation treatments. The graph shows the weight percentage of each group size. A - 'Hanoch'; B - A80; C - B18, -14 - unwanted pod size; EF extra fancy; $\mathrm{G}$ - giant; $\mathrm{SG}$ - super giant

The effect of irrigation and genotype on pod color components (i.e., brightness, redness, yellowness) was studied using a colorimetric system. The results of the ANOVA test are presented in Table 6. Irrigation level significantly affected all of the pod color components: brightness $\left(\mathrm{L}^{*}\right)$, redness $\left(\mathrm{a}^{*}\right)$ and yellowness $\left(\mathrm{b}^{*}\right)$. Significant genotype effect was observed for the $\mathrm{L}^{*}$ and $\mathrm{b}^{*}$ components, but not for $\mathrm{a}^{*}$ component. The interaction between genotype and irrigation had no significant effect on any of the color components. Therefore, the differences between the genotypes and the differences between the irrigation treatments with relation to these traits were analyzed separately (Table 7). 
Table 6. ANOVA tests for the effects of three Virginia-type peanut genotypes, four irrigation levels and their interaction on pod color variables. Significant factors (Prob $(F)<0.05$ ) are indicated by bold type

\begin{tabular}{llllll}
\hline Trait & Source & SS & DF & F ratio & Pro(F) \\
\hline $\mathrm{L}^{*}$ & Block\&Random & 12.89 & 3 & 4.29 & $\mathbf{0 . 0 0 3 6}$ \\
& Irrigation & 17.73 & 3 & 7.51 & $\mathbf{0 . 0 0 0 5}$ \\
& Genotype & 10.34 & 2 & 6.57 & $\mathbf{0 . 0 0 3 9}$ \\
& Irrigation $\times$ Genotype & 3.65 & 6 & 0.77 & 0.595 \\
\hline $\mathrm{a}^{*}$ & Block\&Random & 3.41 & 3 & 7.77 & $\mathbf{0 . 0 0 0 4}$ \\
& Irrigation & 5.66 & 3 & 12.90 & $<\mathbf{0 . 0 0 0 1}$ \\
& Genotype & 0.71 & 2 & 2.43 & 0.11 \\
& Irrigation $\times$ Genotype & 0.97 & 6 & 1.11 & 0.38 \\
\hline $\mathrm{b}^{*}$ & Block\&Random & 4.67 & 3 & 1.44 & 0.24 \\
& Irrigation & & 3 & 6.88 & $\mathbf{0 . 0 0 1}$ \\
& Genotype & 19.46 & 2 & 9.01 & $\mathbf{0 . 0 0 0 7}$ \\
& Irrigation $\times$ Genotype & 11.03 & 6 & 1.70 & 0.15 \\
\hline
\end{tabular}

$\mathrm{L}^{*}=$ brightness; $\mathrm{a}^{*}=$ redness; $\mathrm{b}^{*}=$ yellowness.

Table 7. Range test for differences between peanut genotypes in terms of pod-color characteristics. Treatments not labeled with the same letter are significantly different from one another

\begin{tabular}{|c|c|c|c|c|c|c|c|c|}
\hline \multicolumn{3}{|l|}{$\mathrm{L}^{*}$} & \multicolumn{3}{|l|}{$a^{*}$} & \multicolumn{3}{|l|}{$b^{*}$} \\
\hline Genotype & LSM (SE) & Group & Genotype & LSM (SE) & Group & Genotype & LSM (SE) & Group \\
\hline Hanoch & $65.94 \pm 0.22$ & A & B18 & $4.16 \pm 0.09$ & A & Hanoch & $31.4 \pm 0.26$ & A \\
\hline B18 & $65.05 \pm 0.22$ & B & A80 & $4.09 \pm 0.09$ & A & B18 & $31.2 \pm 0.26$ & A \\
\hline A 80 & $64.45 \pm 0.22$ & B & Hanoch & $3.88 \pm 0.09$ & $\mathrm{~A}$ & A 80 & $29.97 \pm 0.26$ & B \\
\hline Irrigation & LSM (SE) & Group & Irrigation & LSM (SE) & Group & Irrigation & LSM (SE) & Group \\
\hline 120 & $66.02 \pm 0.26$ & $\mathrm{~A}$ & 60 & $4.56 \pm 0.11$ & $\mathrm{~A}$ & 60 & $31.87 \pm 0.30$ & $\mathrm{~A}$ \\
\hline 100 & $65.69 \pm 0.26$ & $\mathrm{AB}$ & 80 & $4.10 \pm 0.11$ & B & 80 & $31.04 \pm 0.30$ & $\mathrm{AB}$ \\
\hline 80 & $65.01 \pm 0.26$ & $\mathrm{BC}$ & 100 & $3.88 \pm 0.11$ & $\mathrm{BC}$ & 100 & $30.54 \pm 0.30$ & $\mathrm{BC}$ \\
\hline 60 & $64.45 \pm 0.26$ & $\mathrm{C}$ & 120 & $3.63 \pm 0.11$ & $\mathrm{C}$ & 120 & $30.03 \pm 0.30$ & $\mathrm{C}$ \\
\hline
\end{tabular}

LSM = Least Square Means. L* = brightness; $a^{*}=$ redness; $b^{*}=$ yellowness.

A range test for the differences between genotypes showed that 'Hanoch' had significantly higher brightness (L*) values than both B18 and A80 (means: 65.94, 65.05 and 64.45, respectively). 'Hanoch' also had the highest yellow $\left(b^{*}\right)$ values (31.4). However, these $b^{*}$ values were significantly different from those of A80 (mean: 29.97), but not those of B18 (mean: 31.2). As stated above, the genotype did not significantly affect the red color component $\left(\mathrm{a}^{*}\right)$. A range test for the differences between the irrigation treatments clearly showed that higher irrigation levels increased the $\mathrm{L}^{*}$ values and decreased both $\mathrm{a}^{*}$ and $\mathrm{b}^{*}$ values. The $80 \%$ irrigation treatment did not cause significantly lower $L^{*}$ values than were observed in the $100 \%$ irrigation treatment (65.01 and 65.69 , respectively), but the $60 \%$ irrigation treatment did (64.45). The $60 \%$ irrigation treatment also had the highest $\mathrm{a}^{*}$ and $b^{*}$ values (4.56 and 31.87, respectively). The same pattern of significance that was observed for L* was also observed for $\mathrm{a}^{*}$ and $\mathrm{b}^{*}$; whereas the $80 \%$ irrigation treatment was not significantly different from the $100 \%$ irrigation treatment, but the $60 \%$ irrigation treatment was significantly different from the $100 \%$ treatment for both factors.

\section{Discussion}

The effect of water stress on peanut yields has been well documented in number of studies. Yet, fewer studies 
have specifically investigated the effect of the level of irrigation on traits related to pod-filling under field conditions. Pod-filling is an extremely important trait for within-shell marketing genotypes and some observations of commercial practices have indicated that lower soil water content may be associated with decreased pod-filling potential. For example, even though drip irrigation has been used very successfully in other crops in Israel, it has not been commercialized for use in peanuts due to the problem of insufficient moisture content in the pod development area, which leads to poor pod-filling. Therefore, the main objective of the study was to investigate the direct effect of irrigation on pod filling-related traits, as well as other traits under field conditions. Previous observations have indicated an effect of genetic variation on pod-filling potential. For that reason, the interactions between the genotypes and the irrigation levels were studied as well.

We found that irrigation level significantly influences pod-filling by reducing seed and pod weights and by increasing the dead-end ratio. On the other hand, the lower irrigation levels did not have any significant effects on total yield per plot or pod size distribution. As previously suggested for peanut (Heuer et al., 1994; Dorner, 2008), the water situation not only influences the mother plants, but also directly affects the development of the seeds. The effect of irrigation level on pod-filling and other pod-related traits was most significant at the lowest irrigation level $(60 \%)$, while there was no difference between $80 \%$ and $100 \%$ irrigation for many other traits (i.e. MC, DE, GPW, PW, SW, L*, a*, b*). For some traits (e.g., MC, DE, GPW, PW, SW), no differences were observed between the $80 \%$ and $120 \%$ irrigation treatments. This indicates that in some cases, it is possible to keep the irrigation levels as low as $80 \%$ without damaging the pod-filling components.

Generally, the use of lower irrigation levels influenced the pod-filling traits in all genotypes with no connection to their basic pod-fill potential under normal conditions. This is reflected in the non-significant Irrigation $\times$ Genotype interaction observed for all of the examined traits, particularly MC and DE. Although this interaction was not statistically significant, Lines 53 and B18 showed particularly large decreases in pod filling-related values when the irrigation level was reduced. This reinforces our previous observations that the pod-filling of these lines is more sensitive to limited water availability.

Interestingly, as mentioned above, the irrigation level did not influence the general pod yield per plot $(\mathrm{Y})$. This indicates that the plant has an ability to compensate for water stress by producing more pods. However, we did not count the actual number of pods per plant. Another interesting observation is that, for some traits like GPW and SW, excess irrigation is not beneficial, but actually harmful. Moreover, for some traits, such as PW and SW, the $80 \%$ irrigation treatment led to better results than the $100 \%$ treatment. Reason for this may be the frequency of watering, which was every 2 days for all irrigation treatments. It is possible that some pod-related traits are influenced by the intervals between irrigation and, therefore, delivery of a volume of water based on $80 \%$ retention every 2 days will not give the same effect as it is applied at longer intervals. Therefore, the effect of intervals between irrigation can be also taken into account in future experiments.

During the growing season, the field in which this experiment was carried out was found to be highly contaminated with the pathogen that causes pod wart disease. Pod wart is characterized by dark growths that occur on the pod's surface but do not damage the pod or seed yield. This gave us the opportunity to investigate the relation of irrigation to the incidence of pod wart among different genotypes and irrigation treatments without affecting other yield related traits. As expected, among the four lines, 53 had the lowest infection levels. This line has been rated as highly tolerant for pod wart and the current trial has once again confirmed its potential for use in breeding programs. A more important result is the effect of irrigation level on pod wart. The use of higher irrigation levels reduced the incidence of pod wart in all genotypes, including those that are very sensitive to this disease. Therefore, irrigating in excess is recommended in plots in which we would expect to find high levels of inoculum.

The irrigation level influences the pod color components. In all of the genotypes, a higher irrigation level led to a significant increase in brightness $\left(\mathrm{L}^{*}\right)$ and decrease in the red $\left(\mathrm{a}^{*}\right)$ and the yellow $\left(\mathrm{b}^{*}\right)$ components. Previous studies of peanut shell color have shown that $a^{*}$ and $b^{*}$ components are inversely correlated with $\mathrm{L}^{*}$, in that $\mathrm{a}^{*}$ is negatively correlated with $\mathrm{L}^{*}$ while $\mathrm{b}^{*}$ is positively correlated with $\mathrm{L}^{*}$ (Ginzberg et al., 2010; Hovav et al., 2012). The current study shows that higher irrigation levels will wash away some soil material from the surface of the shell, leading to a brighter tint, as it was also reported by Ginzberg et al. (2010). This process, however, has some negative effects as well, since heavy irrigation also washes away natural yellowish material from the outer shell. However, under these specific experimental conditions, the former effect was stronger than the latter, leading to brighter pods. This recommends irrigating genotypes with natural stronger yellowish tint to excess, in order to brighten the pods by washing away the red soil component from the pod surface. 


\section{Acknowledgements}

KG thanks ARO Post-Doctoral Fellowship, Israel for financial assistance. This study was funded by the Israel-USA Binational Agricultural Research and Development Fund (BARD). The authors wish to thank Mr. Ilan Hedvat for his technical assistance in the field.

\section{References}

Agarwal, G. K., \& Thelen, J. J. (2006). Large scale identification and quantitative profiling of phosphoproteins expressed during seed filling in oilseed rape. Molecular \& Cellular Proteomics, 5(11), 2044-2059. http://dx.doi.org/10.1074/mcp.M600084-MCP200

Boote, K. J., Varnell, R. J., \& Duncan, W. C. (1976). Relationship of size, osmotic concentration, and sugar concentrations of peanut pods to soil water. Proceedings - Soil \& Crop Science Society of Florida, 35, 47-50. Retrieved from http://aims.fao.org/aos/agrovoc/c_25189

Clements, J. C., Dracup, M., \& Galwey, N. (2002). Effects of genotypes and environment on proportion of seed hull and pod wall in lupin. Australian Journal of Agricultural Research, 53, 1147-1154. http://dx.doi.org/10.1071/AR01156

Dorner, J. W. (2008). Relationship between kernel moisture content and water activity in different maturity stages of peanut. Peanut Science, 35, 77-80. http://dx.doi.org/10.3146/PS07-101.1

Ginzberg, I., Tubi, A., Buchshtab, O., Wininger, S., Ben-Dor, B., Fogelman, E., \& Kapulnil, Y. (2010). Soil type and wetness affect tint of peanut (Arachis hypogaea L.) Pod Shell. Peanut Science, 37, 144-150. http://dx.doi.org/10.3146/PS09-028.1

Harris, D., Matthews, R. B., Nageswara Rao, R. C., \& Williams, J. H. (1988). The physiological basis for yield differences between four genotypes of groundnut (Arachis Hypogaea) in response to drought. III. Developmental processes. Experimental $\quad$ Agriculture, $215-226$. http://dx.doi.org/10.1017/S0014479700015969

Heuer, B., Schaffer, A., Meiri, A., Badani, B., Ben-Dor, B., Fogelman, M., \& Kapulnik, Y. (1994). Irrigation regimes and their effects on peanut seed quality. Agronomy Journal, 3, 169-174.

Hovav, R., Badani, H., Ginzberg, I., Brand, Y., Chedvat, I., \& Galili, S. (2012). Evaluation of a peanut collection for shell color traits under different soil types. Plant Breeding, 131, 148-154. http://dx.doi.org/10.1111/j.1439-0523.2011.01916.x

Kadhem, F. A., Sprecht, J. E., \& Williams, J. H. (1985). Soybean irrigation serially timed during stages RI to R6 II. Yield component responses. Agronomy Journal, 299 -304. http://dx.doi.org/10.2134/agronj1985.00021962007700020026x

Mahon, J. D., \& Hobbs, S. L. A. (1983). Variability in pod filling characteristics of peas (pisum sativum 1.) under field conditions. Canadian Journal of Plant Science, 63(1), 283-291. http://dx.doi.org/10.4141/cjps83-027

Mera, M., Jerez, R., Miranda, H., \& Rouanet, J. (2004). Seed coat specific weight in Lupinus angustifolius: Influence of genotype and environment and relationship with seed coat proportion. Australian Journal of Agricultural Research, 55, 1189-1195. http://dx.doi.org/10.1071/AR04095

Mienke, D., Chen, J., \& Beachy, R. (1981). Expression of storage-protein genes during soybean seed development. Planta, 153, 130-139. http://dx.doi.org/10.1007/BF00384094

Moctezuma, E. (2003). The peanut gynophore: A developmental and physiological perspective. Canadian Journal of Botany, 81(3), 183-190. http://dx.doi.org/10.1139/b03-024

Momen, N. N., Carlson, R. E., Shaw, R. H., \& Arjmand, O. (1979). Moisture stress effects on the yield components of two soybean cultivars. Agronomy Journal, $71, \quad 86-90$. http://dx.doi.org/10.2134/agronj1979.00021962007100010022x

Ono, Y., Nakayama, K,. \& Kubota, M. (1974). Effects of soil temperature and soil moisture in podding zone on pod development of peanut plants. Proceeding Crop Science Society of Japan, 43, $247-251$. http://dx.doi.org/10.1626/jcs.43.247

Rao, R., Nageswara, C., Williams, J. H., \& Singh, M. (1989). Genotypic sensitivity to drought and yield potential of peanut. Agronomy http://dx.doi.org/10.2134/agronj1989.00021962008100060009x

Reddy, T. Y., Reddy, V. R., \& Anbumozhi, V. (2003). Physiological responses of groundnut (Arachis hypogea L.) 
to drought stress and its amelioration: A critical review. Plant Growth Regulation, 41(1), 75-88. http://dx.doi.org/10.1023/A:1027353430164

Rubel, A., Rinne, R., \& Canvin, D. (1972). Protein, oil, and fatty-acid in developing soybean seeds. Crop Science, 12, 739-741. http://dx.doi.org/10.2135/cropsci1972.0011183X001200060006x

Shem-Tov, Y., Chedvat, I., Brand, Y., \& Hovav, R. (2011). New genetic resources for pod-wart disease in peanuts. Nir Vatelem (Hebrew reviewed journal), 5, 14-19.

Smal, H., Kvien, C. S., Sumner, M. E., \& Csinos, A. S. (1989). Solution calcium concentration and application date effects on pod calcium uptake and distribution in florunner and tifton8 peanut. Journal of Plant Nutrition, 12(1), 37-52. http://dx.doi.org/10.1080/01904168909363934

Sorooshzadeh, A., \& Barthakur, N. N. (1995). Moisture stress and calcium absorption from immersions during the seed-filling stage of soybean. Communications in Soil Science and Plant Analysis, 26(13-14), 2309-2318. http://dx.doi.org/10.1080/00103629509369448

Soler, C. M. T., Suleiman, A., Anothai, J., Flitcroft, I., \& Hoogenboom, G. (2013). Scheduling irrigation with a dynamic crop growth model and determining the relation between simulated drought stress and yield for peanut. Irrigation Science, 31(5), 889-901. http://dx.doi.org/10.1007/s00271-012-0366-9

Underwood, C. V., Taylor, H. M., \& Hoveland, C. S. (1971). Soil physical factors affecting peanut pod development. Agronomy Journal, http://dx.doi.org/10.2134/agronj1971.00021962006300060042x

Walerstein, I. (2003). Annual report of peanut breeding in Israel. The Israeli peanut production and marketing council.

Westgate, M. E., \& Grant, D. T. (1989). Effect of water deficits on seed development in soybean. I. Tissue water status. Plant Physiology, 91, 975-979. http://dx.doi.org/10.1104/pp.91.3.975

Westgate, M. E., Schussler, J. R., Reicosky, D. C., \& Brenner, M. L. (1989). Effect of water deficits on seed development in soybean. II. Conservation of seed growth rate. Plant Physiology, 91, 980-985. http://dx.doi.org/10.1104/pp.91.3.980

Wright, G. C., Hubick, K. T., \& Farquhar, G. D. (1991). Physiological analysis of peanut cultivar response to timing and duration of drought stress. Australian Journal of Agricultural Research, 42, 453-470. http://dx.doi.org/10.1071/PP9880815

Zharare, E. G., Blamey, F. P. C., \& Asher, C. J. (2009). Calcium Nutrition of Peanut Grown in Solution Culture. II. Pod-zone and Tissue Calcium Requirements for Fruiting of a Virginia and a Spanish Peanut. Journal of Plant Nutrition, 32(11), 1843-1860. http://dx.doi.org/10.1080/01904160903242359

\section{Copyrights}

Copyright for this article is retained by the author(s), with first publication rights granted to the journal.

This is an open-access article distributed under the terms and conditions of the Creative Commons Attribution license (http://creativecommons.org/licenses/by/3.0/). 